\title{
Nigrosine Staining of Wheat Endosperm Proteolipid Patterns on Starch Gels
}

We have previously characterized a group of proteolipids from wheat endosperm, designated $\mathrm{CM}$ proteins, which are soluble in chloroformmethanol $(2: 1, v / v)$ and have a molecular weight lower than 25,000 daltons (1-3). These have been also studied by Redman and Ewart (4).

The CM proteins are suitably fractionated into several components by starch gel electrophoresis at $\mathrm{pH} 3.2$ (1). A sensitive staining procedure was required in connection with genetic studies of these proteins because phenotypes had to be ascertained in small endosperm fractions dissected without impairing normal germination and plant development. We report here on Nigrosine staining conditions for $\mathrm{CM}$ proteins under which high sensitivity and selectivity are achieved.

\section{MATERIAL AND METHODS}

Common wheat flour (Triticum aestivum L., var. Candeal) was defatted with 4 voi of diethyl ether and extracted with 5 vol of chloroform:methanol $(2: i, v / v)$. The solvent was evaporated under vacuum at $40^{\circ} \mathrm{C}$ and the crude extract stored at $-15^{\circ} \mathrm{C}$.

Horizontal electrophoresis was performed on starch gels $(27 \times 32 \times 0.7 \mathrm{~cm})$ in aluminium lactate/lactic acid buffer, $\mathrm{pH} 3.2,3 \mathrm{M}$ urea, for $7 \mathrm{hr}$ at $10 \mathrm{~V} / \mathrm{cm}(5)$. Samples of $100 \mu \mathrm{g}$ of crude extract were inserted in Whatman no. 3 paper $(7 \times 10 \mathrm{~mm})$. Water soluble Nigrosine (Fluka catalog no. 72470 ) was used at two concentrations $(0.5$ and $65 \%$ ) in three different solvent systems: methanol-water-acetic acid $(5: 5: 1)$ (6-8), water-acetic acid (1:1) $(9,10)$, and $2 \%$ trichloroacetic acid (TCA) (11-13). A staining time of $14 \mathrm{hr}$ was allowed for the $0.5 \%$ Nigrosine solutions and of $20 \mathrm{~min}$ of those at $6 \%$. Amido Black $10 \mathrm{~B}$ (Merck catalog no. 1167) was also used at $6 \%$ in methanol-water-acetic acid $(5: 5: 1)$ for $20 \mathrm{~min}$. Destaining was always carried out with $70 \%$ ethanol after rinsing with tap water.

Comparison of staining conditions was carried out by reflectance densitometry (Chromoscan, Joyce \& Loebl, $654 \mathrm{~nm}$ filter) of identical sliced halves of the gel, stained with cut surfaces facing up.

The crude extract, which includes classical gliadins and glutenins besides $C M$ proteins, was fractionated on Sephadex G-100 $(2.6 \times 90 \mathrm{~cm}$ column, same buffer as electrophoresis). The $\mathrm{CM}$ protein/gliadin ratio from the gel filtration profile was used as reference for the staining ratios observed under different conditions. 


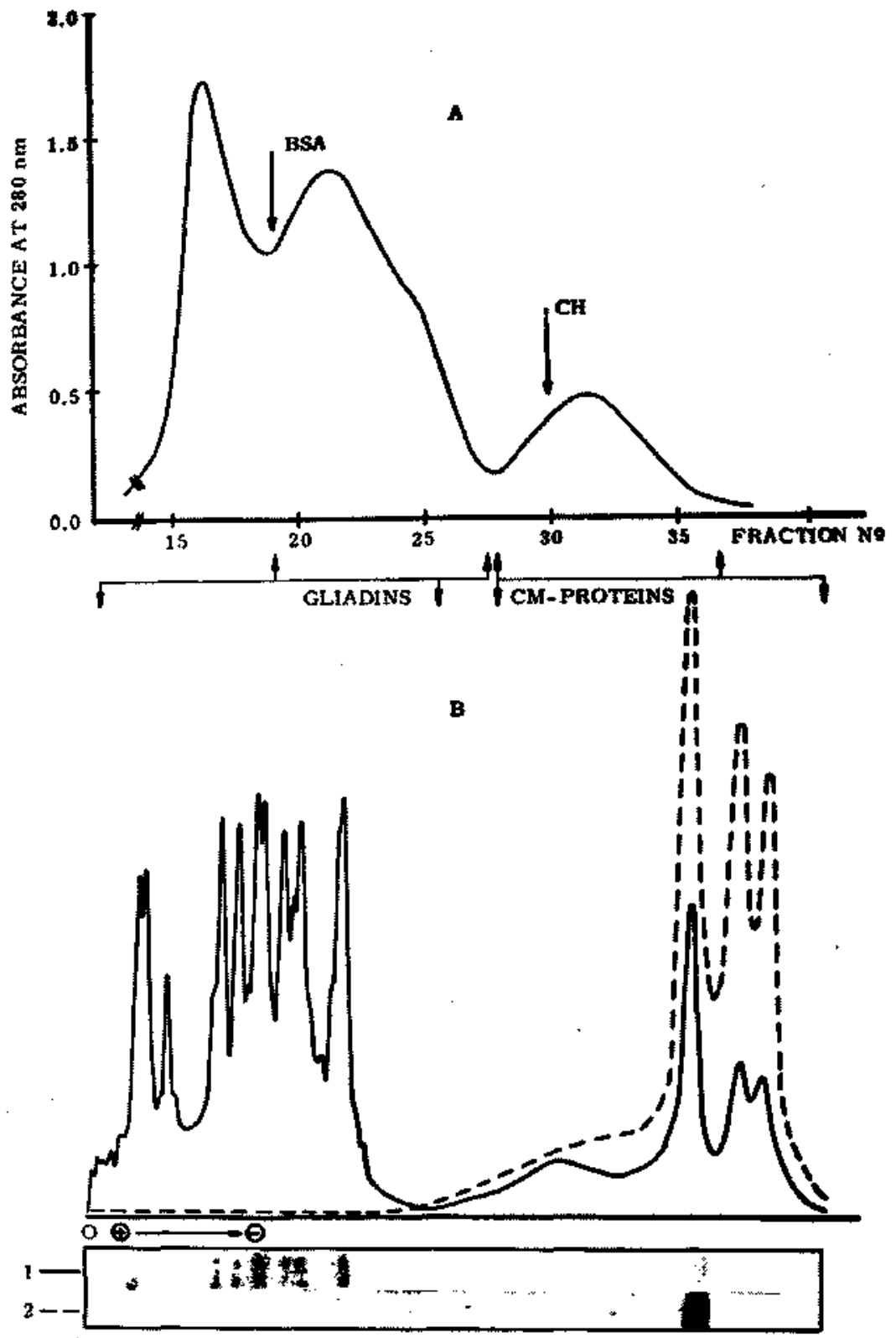

FIG. I. (A) Sephadex G.100 fractionation of chloroform-methanol $(2: l, v / v)$ extracted protein from wheat endosperm. Column calibrated with bovine serum aibumin (BSA) MW 67,000 and chymotrypsinogen (CH) MW 25,000. (B) Densitograms of starch gel electrophoresis patterns of the same protein stained with $(1)(-$, solid line) $6 \%$ Nigrosine in methanol-water-acetic acid $(5: 5: 1)$ and $(2)(-\ldots$, broken line) $0.5 \%$ Nigrosine in wateracetic acid $(1: 1)$. 


\section{RESULTS AND DISCUSSION}

Nigrosine has been extensively used in staining wheat endosperm protein patterns since it was first suggested for that purpose by Coulson and Sim (14).

The great variety of staining conditions employed can be grouped into low concentration-long time $(0.07-0.5 \%, 12-16 \mathrm{hr})$ and high concentration-short time $(1.2-6 \%, 5-30 \mathrm{~min})$ procedures $(6-16$, and others). No staining has been achieved with low concentration-short time and very high background staining results with high concentration-long time. Different mixtures of methanol-water-acetic acid and water-acetic acid, as well as $2 \%$ TCA, have been used as stain solvents.

We have compared the two types of staining procedures and the three types of solvent systems. A gel filtration profile showing the proportion of gliadins and $\mathrm{CM}$ proteins in the crude chloroform-methanol extract is shown in Fig. IA. The results of the electrophoretic staining experiments carried out with this extract are summarized in Fig. 1B. CM proteins were best stained with the more dilute Nigrosine $(0.5 \%)$ in wateracetic acid $(1: 1)$ or in methanol-water-acetic acid $(5: 5: 1)$, sharply but slightly stained in the latter solvent with $6 \% 0 \mathrm{Nigrosine}$, and not stained at all with $0.5 \%$ Nigrosine in $2 \%$ TCA and with $6 \%$ Nigrosine in wateracetic acid $(1: 1)$ or in $2 \%$ TCA. Best results for gliadins were obtained with $6 \%$ Nigrosine in the methanol-water-acetic acid mixture. Dilute Nigrosine $(0.5 \%$ ) in the same solvent slightly stained the faster moving gliadins. Diffuse or no staining resulted under the other conditions tried. Neither CM proteins nor gliadins were stained with Amido Black 10B using the same sample size.

The above results indicate that $\mathrm{CM}$ protein patterns can be adequately detected inserting $1.5-3 \mu \mathrm{g} / \mathrm{mm}^{2}$ of crude extract. A suitable procedure for 5-10 $\mathrm{mg}$ of wheat endosperm is to extract with $25-50 \mu \mathrm{l}$ of chloroform: methanol $(2: 1, v / v)$, to transfer with a capillary tube to a Whatman no. 3 paper $(5 \times 1 \mathrm{~mm})$, evaporating in the process, and to insert in a $1 \mathrm{~mm}$ thick starch gel.

\section{REFERENCES}

1. Garcia Olmedo, F.. and Garcia Faure, R. (1969) Lebensm. Wiss Technol. $2,94$.

2. Garcia Olmedo, F., and Carbonero, P. (1970) Phytochemistry 9, 1495.

3. Aragoncillo, C. (1973) Dr. Ing. Agr. Thesis, Polytechnical University of Madrid.

4. Redman, D. G., and Ewart, J. A. D. (1973) J. Sci. Fd. Agric. 24, 629.

5. Woychick, J. H., Boundy, J. A., AND Dimler, R. J. (1961) Arch. Biochem. Biophys. 94, 477.

6. Graham, J. S. D. (1963) Aust. J. Biol. Sci. 16, 342.

7. Wrigley, C. W. (1965) Aust. J. Biol. Sci. 1, 193.

8. Boyd, W. J. R., LeE, J. W, AND WRIGLeY, C. W. (1969) Experientia 25, 317.

9. Felllet, P. (1965) Ann. Technol. Agr. 14, Hors serie: 1. 
10. Solari, R., and Favret, E. A. (1968) in Mutations in Plant Breeding, Vol. 2, pp. 219-231, IAEA. Vienna.

It. Elton, G. A. H., and Ewart. J. A. D. (1964) J. $S$ ci. Fd. Agric. 15, 119.

12. EWART, J. A. D. (1966) J. Sci. Fd. Agric. 17, 526.

13. Yong, F. C., and Unrau. A. M. (1964) Can. J. Biochem. 42, 1647.

14. Coulson, C. B., ANd SIM, A. K. (1961) Biochem. J. 80, 46P.

15. Tomoyoshi Mita and Daizo Yonezawa (1971) Agr. Biol. Chem. 35, 1972.

16. Jennings, A. C. (1968) Alust. J. Biol. Sci. 21, 1053.

\section{Aragoncillo \\ M. A. RODRIGUEZ-LOPERENA \\ Pilar Carbonero \\ F. Garcia-Olmedo}

Department of Biochemistry

E. T. S. Ingenieros Agronomos

Universidad Politécnica de Madrid

Madrid-3, Spain

Received May 4, 1974; accepted September 4, 1974 